\title{
Technical Efficiency of Beef Cattle Breeding Business in East Java Province
}

\author{
L. S. Kalangia ${ }^{a, b, \#, *}$, Y. Syaukat $^{c, \#}$, S. U. Kuntjoro ${ }^{c, \#}$, \& A. Priyanti ${ }^{\mathrm{d}}$ \\ aStudy Program of Agricultural Economics, Faculty of Economics and Management, Graduate School, \\ Bogor Agricultural University \\ bDepartment of Social Economics, Faculty of Animal Science, Sam Ratulangi University \\ Manado 95115, Indonesia \\ 'Faculty of Economics and Management, Bogor Agricultural University

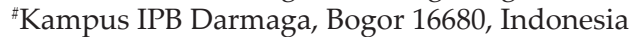 \\ Indonesian Center for Animal Research and Development \\ Bogor, Indonesia \\ (Received 23-04-2014; Reviewed 19-05-2014; Accepted 17-07-2014)
}

\begin{abstract}
The objectives of this research were to compare technical efficiency of beef cattle business operating in lowland and upland areas of East Java and to identify and analyze factors affecting the technical efficiency as well as inefficiency of that business. A survey was conducted to 89 farmers in the lowland area of Probolinggo District and 97 farmers in the upland areas of Malang Districts during the period of February-March 2013. Results of stochastic frontier production function with MLE method showed that the average technical efficiency in lowland area was higher $(80 \%)$ compared to that in upland area $(64 \%)$. The results indicated that beef cattle production was highly significant and positively influenced by total of grasses and forages, rice straw, feed supplements, stock of cattle, labor time allocation and service per conception. However, location of the business, whether in lowland and upland areas was a significant factor that could increase the efficiency. Some factors that could significantly reduce the technical inefficiency of beef cattle business were: labor force in family, education level, proportion of beef cattle income to total household income, age of cattle sold, cattle health examination, ownership status of the cattle, and gender. Therefore, (1) the existing farmers group should be improved their role to facilitate trading of cattle feed, and (2) the government should facilitate the farmers in the provision of funding tu buy beef cattle with a subsidized interest rate, so the farmers will be more enthusiast in taking care of their cattle, thus could improve their production efficiency.
\end{abstract}

Key words: beef cattle breeding, Maximum Likelihood Estimation, technical efficiency, stochastic frontier

\section{ABSTRAK}

Penelitian ini bertujuan untuk membandingkan efisiensi teknis perkembangbiakan sapi potong di dataran rendah dan dataran tinggi di Jawa Timur, serta untuk mengidentifikasi dan menganalisis faktor-faktor yang mempengaruhi efisiensi teknis dan penyebab terjadinya inefisiensi dalam usaha tersebut. Penelitian dilakukan di Kabupaten Probolinggo dan Malang, Jawa Timur pada bulan FebruariMaret 2013. Survei dilakukan terhadap 89 peternak responden di dataran rendah (Probolinggo) dan 97 peternak responden di dataran tinggi (Malang). Hasil estimasi fungsi produksi stokastik frontier dengan metode maximum likelihood estimation (MLE) menunjukkan bahwa rata-rata efisiensi teknis di dataran rendah lebih tinggi $\mathbf{8 0} \%$ ) dibandingkan dengan tingkat efisiensi teknis di dataran tinggi (64\%). Hasil analisis menunjukkan bahwa jumlah rumput dan hijauan, jerami, pakan suplemen, stok ternak sapi, dosis IB, dan lokasi secara signifikan dan positif berpengaruh pada produksi ternak sapi potong. Faktor-faktor yang secara signifikan dapat menurunkan inefisiensi teknis ialah angkatan kerja dalam keluarga, tingkat pendidikan, share pendapatan usaha ternak sapi terhadap total pendapatan rumah tangga, penjualan ternak di bawah satu tahun, pemeriksaan kesehatan ternak, status kepemilikan induk ternak sapi, dan peran gender. Oleh karena itu, (1) perlunya pembentukan kelompok petani peternak yang bisa memfasilitasi jual-beli pakan, dan (2) perlunya bantuan dana pembelian sapi dengan bunga bersubsidi dari pemerintah sehingga peternak dapat memelihara induk milik sendiri untuk meningkatkan efisiensi usaha perkembangbiakan ternak sapi potong.

Kata kunci: perkembangbiakan sapi potong, maximum likelihood estimation, efisiensi teknis, stokastik frontier

*Corresponding author:

E-mail: lidya_kalangi@yahoo.com 


\section{INTRODUCTION}

Meat is an irreplaceable animal protein and is indispensable for the growth of human body. Meat self-sufficiency program, beef in particular, is one of government's programs in fulfilling the needs of beef. General Directorate of Livestock (2011) stated that Beef Self-Sufficiency Program (renewed with Cattle and Beef Self-Sufficiency Program or CBSSP) would be achieved if minimum $90 \%$ of total beef consumption could be supplied from domestic production. Currently, Indonesia imports $35 \%$ of total beef consumption.

Indonesia will constantly depend on imports if the gaps between production and consumption of beef cannot be minimized. Beef Self-Sufficiency Program is targeting a reduction in the import dependence of beef and new feeder cattle. Indonesia's Directorate General of Livestock and Animal Health Services (2011) stated that the self-sufficiency program was not merely directed to meet the consumer needs by limiting beef import, but also to increase domestic beef production, farmers' welfare, and competiveness and sustainability of cattle business in Indonesia.

One of solutions that can be conducted to increase beef production is to continuously increase efficiency of beef cattle business in the country. This target can be achieved through improvement on the use of production inputs (feeds), the use of quality breeds, management and animal health, and technological innovation and other external factors. The availability of local resources and technology has to be supported by government policies and programs to develop business opportunities of the domestic cattle.

Great potential of local resources such as the availability of agricultural waste as cheap feed source, can be an excellence factor for the development of beef cattle farms. In the pursuit of self-sufficiency in beef, improvement in production efficiency is unavoidable. Currently, most of the cattle in Indonesia are raised by the traditional farmers lived in the rural area. The main factors that constraint the efforts to increase cattle productivity in Indonesia are social and economic conditions of the farmers (cattle raisers) who generally have low education and limited capital. This situation has implied on the ownership and patterns of cattle raising (Winarso et al., 2005; Kuswaryan et al., 2004; Sodiq \& Budiono, 2012).

Beef cattle breeding require technological innovation, for both small and large scale farms. Efficiency of cattle business depends on the use of inputs and technology, including selection techniques and animal mating arrangement. Obstacle factors that are currently presumed to be the cause of low productivity of cattle in Indonesia include un-optimal rearing system, which are characterized by the extensive (traditional) management system, side business (not for profit) orientation, and less intensive in using production inputs (Suryana, 2009).

East Java is one of beef cattle production centers with 4.7 million of cattle population (Ditjennak 2011). Geographically, East Java has various terrains, from lowland to upland in the mountain areas, that suitable for cattle production since there are many agricultural wastes and by product that can be used for livestock feeds. Thus, it can provide business opportunities in cattle development that could increase labor opportunity and income to the farmers.

In a farming business, location is one of the important aspects that should be considered so that the business can effectively and efficiently operate. Lowland, in East Java as well as in other areas of Java, is an area with many crops and their wastes can be used as feeds for cattle. Iskandar (2011) stated that local Ongole cows in the upland had better performances of reproduction than in lowland. In addition, Fleming et al. (2010) stated that tropically adapted breeds had relatively higher productivity than temperate-developed breeds.

Most of the previous research results indicate that factors such as feed, breed, input cost, animal health management, age weaning, and farmers' age, experience, education and participation in the groups, affect the level of efficiency in the production of cattle breeding business (Wang et al., 2013; Rakipova et al., 2003; Fleming et al., 2010; Sidauruk et al., 2010). Therefore, the assessment of the technical efficiency of beef cattle breeding business based on agro-ecosystem zone is an important scientific work as a guide in determining a beef cattle enterprise development policy.

The objectives of this paper are: (1) to compare technical efficiency of cattle breeding business in the lowlands and the uplands of East Java, and (2) to identify and analyze the factors that influence the technical efficiency and the causes of technical inefficiency in the beef cattle business.

\section{METHODS}

\section{Location of Survey}

The research was conducted in Probolinggo District, representing lowland area, and Malang district, representing upland area, in February-March 2013. Data were obtained from interviews using a structured questionnaire on household beef cattle farmers who have parents stock of local Ongole cattle (PO). The two selected districts were purposively determined by considering the agro-ecosystem zones-lowlands and uplands and the total population of the PO cattle. Both districts have the highest PO cattle population in East Java Province. Probolinggo has an altitude between 0 to $250 \mathrm{~m}$ above sea level, while Malang's altitude is about 500 meters above sea level.

\section{Sampling Methods}

One sub-district with the highest population of $\mathrm{PO}$ cattle was selected from each district. The selected subdistricts were Tongas (in Probolinggo) and Bantur (in Malang). Sample villages were also selected based on the highest PO cattle population. The selected villages were: Curahtulis and Tambakrejo (in Probolinggo), and Srigonco (in Malang). 
Since the information about farmers who had PO cattle was not available, the samples were derived from snowball sampling technique, a purposive sampling techniques based on the previously interviewed (Sukandarrumidi, 2012). The total number of interviewed respondents was 186 respondents, consisting of 89 respondents in the lowlands and 97 respondents in the uplands. They were chosen according to two conditions: (1) the farmers have been raising PO cattle for more than $2 \mathrm{y}$, and (2) they still have 1 ever mated breeding, and have ever sold their livestock.

\section{Analysis of Production Function Model Stochastic Frontier}

A natural logarithmic model was used to estimate explanatory variables that were affecting technical efficiency in beef production and operation, with the farmers' household as the unit of analysis. In this study, production (body weight gain) was assumed as a proxy of the selling price of cattle produced by a mother cow within the last 1 year (recall of 1 year data was done from February 2012 to January 2013). If the sold young cattle were produced by a mother cow before this study, the selling price was then deducted by its selling price in the early year of the study (February 2012).

Weight of calves or young cattle produced and/or sold in a one year production process (February 2013 to March 2013) was determined as dependent variable. This dependent variable was assumed to be affected by the total amount of grasses, forages, rice straw, feed supplement, stock of cattle, allocation of time of labor to cut forage, rice straw, and grass, and the service per conception (S/C) of artificial insemination (AI) applied to productive cow and were calculated for 1 last year.

The stochastic frontier production function model (Wang et al., 2013; Essilfie et al., 2013; Asogwa et al., 2011) was formulated as follows:

$\ln Y_{i}=\beta_{0}+\beta_{1} \ln X_{1 \mathrm{i}}+\beta_{2} \ln X_{2 \mathrm{i}}+\beta_{3} \ln \mathrm{X}_{3 \mathrm{i}}+\beta_{4} \ln \mathrm{X}_{4 \mathrm{i}}+\beta_{5} \ln \mathrm{X}_{5 \mathrm{i}}+$ $\beta_{6} \ln \mathrm{X}_{6 \mathrm{i}}+\alpha \mathrm{D}\left(\mathrm{v}_{\mathrm{i}}-\mathrm{u}_{\mathrm{i}}\right) \ldots .(1)$

where: $Y=$ production of beef cattle sold ( $\mathrm{kg}$ per year); $X_{1}=$ total grasses and forages $\left(\mathrm{kg}\right.$ per year); $X_{2}=$ total rice straw (kg per year); $X_{3}=$ total feed supplements $(\mathrm{kg}$ per year); $X_{4}=$ total stock of cattle; $X_{5}=$ labor time allocation (hours per year); $X_{6}=$ Service per conception (IU/mg); $\mathrm{D}=$ dummy for location ( 1 for the uplands and 0 for the lowlands); $\mathrm{i}=$ the respondent (farmer) for $\mathrm{i}=(186) ; \beta_{\mathrm{i}}=$ estimated coefficients parameter $\left(\beta_{\mathrm{i}}>0 ; \mathrm{i}=6\right)$; and $\mathrm{v}_{\mathrm{i}}-\mathrm{u}_{\mathrm{i}}=$ inefficiency effect technique in model.

\section{Analysis of Technical Efficiency and Technical Inefficiency}

Apart from technical efficiency, this research also examined the technical inefficiency. Technical inefficiency method that was used in this research referred to the technical inefficiency effect models developed by Asogwa et al. (2011), Oyewo (2011), Ogundari (2008), and Essilfie et al. (2011). Determination of technical inefficiency factors resource used in a multiple linear regres- sion model which were simultaneously estimated under the frontier production function. Variable $u_{i}$ was used to measure the technical inefficiency effects, which was assumed to be free and truncated normal distribution with $\mathrm{N}\left(\mu_{\mathrm{i}}, \sigma^{2}\right)$. Technical inefficiency model mathematically was formulated as follows:

$\mathrm{u}_{\mathrm{i}}=\delta_{0}+\delta_{1} Z_{1 \mathrm{i}}+\delta_{2} Z_{2 \mathrm{i}}+\delta_{3} Z_{3 \mathrm{i}}+\delta_{4} \mathrm{D}_{1 \mathrm{i}}+\delta_{5} \mathrm{D}_{2 \mathrm{i}}+\delta_{6} \mathrm{D}_{3 \mathrm{i}}+\delta_{7} \mathrm{D}_{4 \mathrm{i}}(2)$

where: $u=$ inefficiency effect; $Z_{1}=$ total of labor force used in household's farming (persons); $Z_{2}=$ length of formal education of the heads of households (years); $Z_{3}=$ share of beef cattle to household income (\%); $\mathrm{D}_{1}=$ dummy for age of cattle sold ( 1 if cattle were sold at the age of $<12$ months, 0 if cattle were sold aged $12-23$ months); $\mathrm{D}_{2}=$ dummy for gender in the cattle operation ( 1 for male and 0 for female); $D_{3}=$ dummy for cattle health checks ( 1 if there was medical examination for sick cattle and vitamin supplies, and 0 for none); $\mathrm{D}_{4}=$ dummy for cattle ownership status ( 1 if the cattle was owned by the farmers and 0 if not); $\delta=$ parameters to be estimated $\left(\delta_{i}<0\right)$.

Estimation of production function parameters and function of inefficiency in equation 1 and equation 2 was done simultaneously by using the Frontier 4.1 program (Coelli 1996). Testing of the parameters of the stochastic frontier and technical inefficiency effects were conducted in two stages. In the first stage, the $\beta_{\mathrm{i}}$ parameter estimation was estimated by using Ordinary Least Squares (OLS) approach. In the second stage, the estimation of all parameters $\delta_{i^{\prime}} \beta_{i}$ and variance of $u_{i}$ and $v_{i}$ was conducted by using Maximum Likelihood (MLE) approach, with confidence level $\alpha$ at 1\%,5\%,10\% and 20\%, respectively.

\section{RESULTS AND DISCUSSION}

\section{Estimation of Stochastic Frontier Production Function of Beef Cattle Breeding in East Java}

The results of the estimated parameters of the Cobb-Douglas production function - equations (1) and (2) - are presented in Table 1 . These results were considered to be the best model to the farmers under the existing inputs and technology used, since all estimator variables of the production function had positive and significant effects on the cow's production. Grasses and forages variable was significant at $\alpha=0.01$, the number of cattle stock was significant at $\alpha=0.05$ level, the amount of rice straw, the labor time allocation, and S/C of AI were significant at $\alpha=0.10$, and feed supplements was significant at $\alpha=0.20$. These results indicated that all of these inputs had a major role in the production of beef cattle. Elasticity of grasses and forages variable was the largest compared to those of all the variables included in the model, indicating that grasses and forages had the dominant contribution to total productivity factors.

Dummy of location parameter was positive and had a significant effect on the level of $\alpha=0.01$. Lowland areas of East Java are usually found to be the center of food crop production, thus resulted in large food crops wastes such as rice straw and corn straw. However, not all cattle farmers had their owned agricultural lands which produce crop waste that could be used to feed their cattle. 
Table 1. The results of the stochastic frontier production function estimation in the beef cattle breeding business using the MLE in East Java Province

\begin{tabular}{lccc}
\hline Variables & Coefficient & Standard Error & t-ratio \\
\hline Constant & -3.7939 & -0.7539 & 5.0325 \\
Total grasses and forages $(\mathrm{kg})$ & $0.6908^{\mathrm{a}}$ & 0.0727 & 9.4954 \\
Total rice straws $(\mathrm{kg})$ & $0.0321^{\mathrm{c}}$ & 0.0168 & 1.9125 \\
Total feed supplements $(\mathrm{kg})$ & $0.0068^{\mathrm{d}}$ & 0.0044 & 1.5640 \\
Total cattle stock $(\mathrm{kg})$ & $0.1677^{\mathrm{b}}$ & 0.0839 & 1.9994 \\
Labor time allocation (hours/year) & $0.1539^{\mathrm{c}}$ & 0.0808 & 1.9056 \\
Service per conception (IU/mg) & $0.1034^{\mathrm{c}}$ & 0.0557 & 1.8540 \\
Dummy location & $0.3246^{\mathrm{a}}$ & 0.0647 & 5.0149 \\
\hline
\end{tabular}

Note: $\mathrm{a}, \mathrm{b}, \mathrm{c}$ and $\mathrm{d}$ significant at $\alpha=0.01, \alpha=0.05, \alpha=0.10$, and $\alpha=0.20$, respectively.

About $52 \%$ of surveyed farmers in the lowlands did not have their owned agricultural lands. In contrary, most of the farmers in the uplands $(78 \%)$ had farms and plantations with cattle farms as their side-business. In this area, the farmers could use the lands for growing grasses and forages, and resulted in crop residues that could be used for their cattle feed. This was the reason why farmers in the uplands have a room to improve technical efficiency.

The opportunity of farmers to improve technical efficiency in uplands was shown by the potential of natural and human resources they have. The higher agricultural and plantation areas in uplands are potential to be used more optimally by using them to grow grasses and other animal-feed plants. Respondents in lowlands (Probolinggo) had done their effort to improve feed quality. This was shown from the finding that they used various feedstuffs (tofu waste, rice bran, molasses, and salt) in their cattle concentrate feed. Meanwhile, in upland (Malang), farmers only used salt and only a few of them fed their cattle with rice bran. This might be caused by the fact that beef cattle farming in uplands was done as a side activity of their main rice farming and plantation business. In addition to gene, environment, and feed, farming management is believed as an important factor affecting reproduction and production of cattle.

\section{Technical Efficiency and Factors Affecting Technical Inefficiency of Beef Cattle Farmers in East Java}

Estimation of the technical efficiency in cattle production was conducted by using Frontier 4.1 software. The frequency distribution of technical efficiency can be seen in Table 2. Average efficiency of the cattle business in the uplands was greater than that in the lowlands. A cattle business was considered to be technically efficient if its value was close to $100 \%$. Based on the results of the research (Table 2), it was about $53 \%$ of the upland farmers whose efficiency was above $70 \%$, and $87 \%$ of farmers in lowland with efficiency levels at above $70 \%$. The average efficiency levels at lowland and upland areas were $80 \%$ and $64 \%$, respectively; indicating that there was a room to improve production efficiency level up to $20 \%$ in the lowland areas, and up to $36 \%$ in the upland areas. These average efficiency levels were smaller than the $95 \%$ found for cow-calf enterprises on Texas Rolling
Plains (Wang et al., 2013) and the 83\% found for technical efficiency of cow-calf farms in Alberta (Samarajeewa et al., 2012).

Factors affecting the cattle business inefficiencies are presented in Table 3. Stochastic frontier production function using the MLE approach was used to examine the factors determining the technical inefficiency in beef cattle production contributed by the characteristics of the farmers including management aspect and other production factors. This inefficiency estimator was affected by the factors of production, as well as farmer's characteristics. The negative sign of an inefficiency parameter indicated that an increase in this variable could lower the technical inefficiency level, whereas the positive sign indicated that an increase in this variable would increase the inefficiency (more inefficient). Value of gamma $(\gamma)$ of Table 3 was 0.96 and significant at $\alpha=$ 0.01 , indicating that $96 \%$ of the variation in technical inefficiency was due to the differences in those production and farmers' characteristic variables and the remainder were caused by external factors such as climate, animal health and diseases, and false modeling.

Table 2. Frequency distribution of technical efficiency of beef cattle farmers in lowlands and uplands in East Java

\begin{tabular}{|c|c|c|c|c|}
\hline \multirow[b]{2}{*}{ Efficiency level } & \multicolumn{2}{|c|}{ Lowland } & \multicolumn{2}{|c|}{ Upland } \\
\hline & $\begin{array}{l}\text { Total of } \\
\text { farmers }\end{array}$ & $\%$ & $\begin{array}{l}\text { Total of } \\
\text { farmers }\end{array}$ & $\%$ \\
\hline $0-10$ & 0 & 0 & 4 & 4 \\
\hline $11-20$ & 0 & 0 & 3 & 3 \\
\hline $21-30$ & 0 & 0 & 3 & 3 \\
\hline $31-40$ & 2 & 2 & 7 & 7 \\
\hline $41-50$ & 0 & 0 & 11 & 11 \\
\hline $51-60$ & 4 & 4 & 4 & 4 \\
\hline $61-70$ & 6 & 7 & 14 & 14 \\
\hline $71-80$ & 16 & 18 & 20 & 21 \\
\hline $81-90$ & 54 & 61 & 25 & 26 \\
\hline $91-100$ & 7 & 8 & 6 & 6 \\
\hline Total & 89 & 100 & 97 & 100 \\
\hline Minimum & \multicolumn{2}{|c|}{32} & \multicolumn{2}{|l|}{4} \\
\hline Maximum & \multicolumn{2}{|c|}{92} & \multicolumn{2}{|c|}{93} \\
\hline Average & \multicolumn{2}{|c|}{80} & \multicolumn{2}{|l|}{64} \\
\hline
\end{tabular}


Table 3. Factors determining technical inefficiency of beef cattle farm in East Java effects: a stochastic frontier production approach

\begin{tabular}{lccc}
\hline Variables & Coefficient & Standard error & t-ratio \\
\hline Constant $\left(\delta_{0}\right)$ & 7.1088 & 0.9884 & 7.1922 \\
Labor Force (person) & $-0.9121^{\mathrm{a}}$ & 0.2034 & -4.4841 \\
Length of Education (year) & $-0.3521^{\mathrm{a}}$ & 0.1076 & -3.2740 \\
Share of beef cattle to household income $(\%)$ & $-0.0572^{\mathrm{a}}$ & 0.0096 & -5.9455 \\
Dummy for age of cattle sold (heifer=0, calf=1) & $-3.1532^{\mathrm{a}}$ & 0.8861 & -3.5585 \\
Dummy for Gender (male=1, female=0) & $-0.5354^{\mathrm{d}}$ & 0.3524 & -1.5194 \\
Dummy for cattle health (yes=1, no=0) & $-2.5922^{\mathrm{a}}$ & 0.7102 & -3.6498 \\
Dummy for cattle ownership status (owned by a farmer=1, share owners=0) & $-1.7138^{\mathrm{a}}$ & 0.4828 & -3.5496 \\
Gamma & $0.9590^{\mathrm{a}}$ & 0.0148 & 65.000 \\
\hline
\end{tabular}

Note: a and d significant at $\alpha=0.01$ and $\alpha=0.20$, respectively.

The difference in technical inefficiency could be caused by various factors among farmers characteristics. Factors affecting the results of the technical inefficiency are presented in Table 3. The results showed that various farmers' characteristics, including number of farmers' labor force, length of formal education, share of livestock income to total household income, age of cattle sold (dummy), gender (dummy), livestock health examination (dummy), and ownership status of the cattle (dummy), had negative signs. This result was in line with expectations, which predicted that an increase in those variables could reduce the technical inefficiency or improve technical efficiency.

Based on the above result and criteria, statistic showed that all of hypothesized variables affected the beef cattle production significantly. Variable of labor force, length of formal education, share of income from the beef cattle business, age of cattle sold dummy, dummy of cattle health inspection and dummy of cattle ownership status respectively were significant at $\alpha=$ 0.01 . While gender dummy was significant at $\alpha=0.20$. It showed that these variables needed attention in order to reduce the technical inefficiency of beef cattle breeding business.

Labor force. Labor force was significant to the production of beef cattle with a negative estimated value of the coefficient (-0.9121). As was expected, the estimation was negative, implying that the use of family labor would reduce inefficiencies in the cattle breeding business. This occurred since the farms used more non family members to search for feed and help with feeding and cleaning barn. Research by Sarma and Ahmed (2011) and Mussa et al. (2012) also showed that the family size is significant in improving the economic efficiency of agriculture business, including cattle business.

Length of education. Years of formal education was significantly influenced technical inefficiency level, with negative parameters (-0.3521). The average level of education in the uplands was higher than that of the lowlands. Education was one of the factors that could improve technical efficiency, since it could improve the managerial capacity of farmers. Education level was important in determining farmers' capacity in understanding information on beef cattle production or other aspects. The negative sign of the length of education to the technical inefficiency indicated the length of farmers' education was an important variable that could improve technical efficiency. This finding agreed with Mlote et al. (2013), and Sarma and Ahmed (2011), that education was one of important factors and indirectly related to the technical efficiency of beef cattle business.

Share of beef cattle business to household income. Share of beef cattle income to total household income significantly affected to cattle production, with negative parameters $(-0.0572)$. This means that the greater share of total income will reduce technical inefficiency or increase the technical efficiency in cattle breeding business. This implies that if farmers focus on their cattle farm operation by allocating more time to feed and care of their cattle, it can increase the production efficiency and thus, income.

Age of cattle sold. Most farmers in the uplands area (75 $\%)$ sold their cattle at the age of 12-23 months, whereas in the lowlands only 35\% who sold their cattle at the age of 12-23 months. Farmers' decision to sell their calves at an older age was to obtain a higher cattle value, since the performance (live weight) of the calves were heavier than if they sell them at the weaning age. The custom of farmers in the lowlands area who often wean their calves by selling them at younger age could be one of the causes of farmers' low income from cattle operation. This condition was usually motivated by the urgent cash needs of the farmers to cover certain expenditures. Dummy of sales of calves under one year old was found to improve significantly the technical efficiency with parameter value was -3.1532 . Selling of calves at weaning would make cows ready to be inseminated and get pregnant sooner. Consequently, calving internal became shorter and target of having one calf every year became easier to meet. The result of this research is in line with the result reported by Suryana (2009) that early weaning can short the calving internal.

Cattle health. The practice of cattle health check up by paramedics or field officers significantly affected the technical inefficiency of livestock production with negative parameters (-2.5922). Therefore, checking the cattle's health could reduce the technical inefficiency. 
Despite having to pay for medicines, vitamins and services rendered by veterinary paramedic, most farmers would call paramedics when they found their cattle were sick. From their previous experience, the farmers believed that their cattle would be healed if it was treated by the paramedics. Some of them treated their cattle with traditional herbs, by utilizing medicinal plants that were found around their home, if their cattle were sick or loosing appetite.

Cattle ownership status. About $31 \%$ of farmers in the uplands area whose beef cattle was partially owned (ownership of the cattle was shared with other persons). This kind of ownership was only about $22 \%$ in the lowlands. The self-ownership status of the cattle was significant in determining efficiency, with negative parameter estimate (-1.7138). Ownership status of the cattle was an important variable in determining efficiency, since self-ownership status of the cattle could reduce technical inefficiency.

Gender. Men and women had different roles in beef cattle business. Men were usually considered to have more skills in mowing grasses, forages and rice straws; while women conducted small but more diverse jobs, including: providing food and drink, and occasionally cleaning the barn. Even, some of them were also involved in mowing grasses and forages. In this research, gender variable $($ male $=1)$ had negative sign and statistically significant at $\alpha=0.20$, as was expected. However, women had potential roles in increasing cattle business efficiency. This result is in line with those results reported by Mussa et al. (2012).

There are some recommendations of the research. First, currently, farmers are facing difficulties in the provision of feed for their beef cattle. Therefore, the existing farmers groups should be improved their role to facilitate the trading of cattle feed, such as rice straw. This is important to maintain the beef cattle production activities and also to improve their production efficiency. Second, the ownership of the cattle matters to the farmers. Since almost half of the respondents do not have their own beef cattle, the government should facilitate the farmers in the provision of funding to buy beef cattle with a subsidized interest rate. With this effort, the farmers will be more enthusiast in taking care of their cattle, thus could improve their production efficiency. These two recommendations could increase farmers' incomes and support the beef self-sufficiency program.

\section{CONCLUSION}

Under the existing condition, technical efficiency in beef cattle breeding in the lowland area has a greater potency to be improved compared to that in the upland areas. Factors that significantly reduce the technical inefficiency of beef cattle business are labor force, length of education, income shares of cattle to total household income, calves sold under one year old, gender, cattle health examination, and cattle ownership status.

\section{REFERENCES}

Asogwa, B. C., J. C. Ihemeje, \& J. A. C. Ezihe. 2011. Technical and allocative efficiency analysis of nigerian rural farmers: implication for poverty reduction. Agricultural Journal 6: 243-251. http://dx.doi.org/10.3923/aj.2011.243.251

Coelli, T. J. 1996. A guide to Frontier Version 4.1 : A Computer Program for Stochastic Frontier Production and Cost Function Estimation. Centre for Efficiency and Productivity Analysis (CEPA) Working Paper 7/96. University of New England, Armidale. (http://www.une.edu.au/econometrics/cepawp.htm)

Essilfie, F. L., M. T. Asiamah, \& F. Nimoh. 2011. Estimation of farm level technical efficiency in small scale maize production in the mfantseman municipality in the central region of Ghana: A stochastic frontier approach. Journal of Development and Agricultural Economics 3: 645-654.

Fleming, E., P. Fleming, G. Griffith, \& D. Johnston. 2010. Measuring beef cattle efficiency in australian feedlots: applying technical efficiency and productivity analysis methods. Australasian Agribusiness Review 18: 43-65.

General Directorate of Livestock. 2011. Blue Print of Beef Selfsufficiency Program 2014. General Directorate of Livestock Ministry of Agriculture, Jakarta.

Iskandar. 2011. Performan reproduksi sapi PO pada dataran rendah dan dataran tinggi di Provinsi Jambi. Jurnal Ilmiah Ilmu-Ilmu Peternakan 14: 51-61.

Kuswaryan, S., S. Rahayu, C. Firmansyah, \& A. Firman. 2004. Manfaat ekonomi dan penghematan devisa impor pengembangan peternakan sapi potong rakyat. Jurnal Ilmu Ternak 4: 41-46.

Mlote, S. N., N. S. Y. Mdoe, A. C. Isinika, \& L. A. Mtenga. 2013. Estimating technical efficiency of small scale beef cattle fattening in the lake zone in Tanzania. Journal of Development and Agricultural Economics 5: 197-207. http://dx.doi. org/10.5897/JDAE12.0436

Mussa, E. C., G. A. Obare, A. Bogale, \& F. P. Simtowe. 2012. Analysis of resource use efficiency in smallholder mixed crop-livestock agricultural systems: empirical evidence from the central uplands of Ethiopia. Developing Country Studies 2: 30-40.

Ogundari, K. 2008. Resource-productivity, allocative efficiency and determinants of technical efficiency of rainfed rice farmers : a guide for food security policy in Nigeria. Journal of Sustainable Development in Agriculture \& Environment 3: 20-33.

Oyewo, I. O. 2011. Technical efficiency of maize production in Oyo State. Journal of Economics and International Finance 3: 211-216.

Priyanti, A., I. G. A. P. Mahendri, F. Cahyadi, \& R. A. Cramb. 2012. Income over feed cost for small to medium scale beef cattle fattening operations in East Java. J. Indonesian Tropical Animal Agric. 37: 195-201.

Rakipova, A. N., J. M. Gillespie, \& D. E. Franke. 2003. Determinants of technical efficiency in Louisiana beef cattle production. Journal of the ASFMRA: 99-107.

Samarajeewa, S., G. Hailu, S. R. Jeffrey, \& M. Bredahl. 2012. Analysis of production efficiency of beef cow/calf farms in Alberta. Appl. Econ. 44: 313-322. http://dx.doi.org/10.1080/ 00036846.2010 .507173

Sarma, P. K, \& J. U. Ahmed. 2011. An economic study of small scale cattle fattening enterprise of Rajbari district. Bangladesh Agricultural University Research System (BAURES) 9: 141-146.

Sidauruk, R., L. Cyrilla, \& J. Atmakusuma. 2010. Analisis efisiensi pola usaha sapi potong di Bekasi Jawa Barat (Kasus di PT Lembu Jantan Perkasa). Med. Pet. 24: 128-135. 
Sodiq, A. \& M. Budiono. 2012. Produktivitas sapi potong pada kelompok tani ternak di pedesaan. J. Agripet. 12: 28-33.

Sukandarrumidi. 2012. Research Methodology: Practical Guidelines for Beginner Researchers. Gadjah Mada University Press, Yogyakarta.

Suryana. 2009. Pengembangan usaha ternak sapi potong Berorientasi agribisnis dengan pola Kemitraan. Jurnal Litbang Pertanian 28: 29-37.
Wang, T., S. C. Park, S. Bevers, R. Teague, \& J. Cho. 2013. Factors Affecting Cow-Calf Herd Performance and Greenhouse Gas Emissions. Journal of Agricultural and Resource Economics 38: 435-456

Winarso, B., R. Sajuti, \& C. Muslim. 2005. Tinjauan ekonomi ternak sapi potong di Jawa Timur. Forum Penelitian Agro Ekonomi 23: 61-71. 